\title{
PEMAHAMAN KONSEP MATEMATIKA DAN KEPERCAYAAN DIRI PESERTA DIDIK MENGGUNAKAN MODEL STUDENT FACILITATOR AND EXPLAINING DENGAN METODE PEER TEACHING
}

\author{
Lailatul Fitria ${ }^{1}$, Mustangin ${ }^{2}$, Isbadar Nursit ${ }^{3}$ \\ ${ }^{1,2,3}$ Pendidikan matematika, Fakultas Keguruan dan Ilmu Pendidikan Universitas Islam Malang \\ Email: ${ }^{1}$ lailatulf887@gmail.com
}

\begin{abstract}
Abstrak
Pemahaman konsep dan kepercayaan diri merupakan dua hal sangat penting bagi peserta didik dalam belajar matematika. Pemahaman konsep dasar matematika menjadi prasyarat dalam pemecahan masalah matematika maupun masalah dalam bidang lain. Di samping pemahaman konsep, kepercayaan diri merupakan salah satu faktor penting dalam pemecahan masalah. Penelitian ini bertujuan untuk mengetahui apakah terdapat perbedaan, mengetahui manakah yang lebih baik dan mendeskripsikan pemahaman konsep matematika dan kepercayaan diri peserta didik antara kelas eksperimen yang menggunakan model pembelajaran Student Facilitator and Explaining dan metode Peer Teaching dengan kelas kontrol yang menggunakan model pembelajaran konvensional pada materi segiempat dan segitiga kelas VII SMP Negeri 2 Sukorejo. Metode yang digunakan dalam penelitian ini adalah metode kombinasi dengan desain Sequantial Explanatory di mana metode kuantitatif pada tahap pertama dan metode kualitatif pada tahap kedua. Hasil penelitian ini yakni terdapat perbedaan pemahaman konsep matematika dan kepercayaan diri peserta didik kelas eksperimen dengan kelas kontrol, pemahaman konsep matematika dan kepercayaan diri peserta didik kelas eksperimen lebih baik daripada kelas kontrol, dan deskripsi pemahaman konsep matematika dan kepercayaan diri peserta didik kelas eksperimen berbeda dari kelas kontrol dilihat dari pencapaian indikator pada masing-masing kategori peserta didik.
\end{abstract}

Kata Kunci: Model Pembelajaran Student Facilitator and Explaing, Metode Peer Teaching, Pemahaman Konsep Matematika, Kepercayaan Diri.

\begin{abstract}
Conceptual understanding and self-confidence are very important things for students in learning mathematics. Understanding the basic concepts of mathematics is a prerequisite for solving mathematical problems and problems in other fields. In addition conceptual understanding, self-confidence is an important factor in problem solving. This study aims to find out whether there are any differences and to know which one is better and describe the understanding of mathematical concepts and self-confidence of students between experimental classes that use Student Facilitator and Explaining learning models and Peer Teaching methods with control classes that use conventional learning models on quadrilateral material and the VII class triangle of Sukorejo Junior High School 2. The method used in this study is a combination method with Sequantial Explanatory design in which the quantitative method in the first stage and the qualitative method in the second stage. The results of this study are different in the understanding of mathematical concepts and self-confidence between the experimental class students and the control class. The understanding of mathematical concepts and self-confidence of experimental class students are better than the control class, and descriptions of understanding mathematical concepts and confidence in experimental class students differ from control class which shown from the achievement of indicators in each category of students.
\end{abstract}

Keywords: Student Facilitator and Explaing Learning Model, Peer Teaching Method, Understanding of Mathematical Concepts, Self Confidence. 


\section{PENDAHULUAN}

Pendidikan merupakan sarana bagi peserta didik untuk menyiapkan generasi masa kini sekaligus masa depan (Solehah, 2016). Jalur yang dilalui peserta didik untuk mengembangkan potensi diri dalam pendidikan melewati tiga jalur, sesuai UU Nomor 20 tahun 2003 Pasal 13 ayat 1 dinyatakan bahwa "jalur pendidikan mempunyai tiga jalur yaitu pendidikan formal, pendidikan non formal, dan pendidikan informal yang saling melengkapi dan memperkaya". Pendidikan formal merupakan pendidikan yang ditempuh peserta didik di bangku sekolah. Dalam pendidikan formal peserta didik dilatih untuk bertanggungjawab dan mengembangkan potensi yang ada pada dirinya. Pada setiap jalur yang dilalui peserta didik, matematika adalah salah satu mata pelajaran yang selalu dipelajari di setiap jenjang pendidikan. Hudojo (2005) matematika adalah ilmu yang berkaitan dengan bentuk dan truktur yang abstrak. Sedangkan Afrilianto (2018) mengemukakan bahwa matematika merupakan salah satu disiplin ilmu dalam dunia pendidikan yang memegang peranan penting dalam perkembangan sains dan teknologi.

Pada pembelajaran matematika, Pemahaman konsep dasar matematika menjadi prasyarat dalam pemecahan masalah matematika maupun masalah dalam bidang lain. Dalam Permendiknas Nomor 22 Tahun 2006 disebutkan tujuan utama pembelajaran matematika adalah memahami konsep matematika, menjelaskan keterkaitan antar konsep dan mengaplikasikan konsep atau algoritma secara luwes, akurat, efisien dan tepat dalam pemecahan masalah. Pemahaman konsep memiliki peran sangat penting karena setiap konsep matematika satu dengan yang lainnya saling berkaitan sehingga untuk mempelajarinya harus sistematis dan berkesinambungan (Purwaningsih, 2016).

Di samping pemahaman konsep, kepercayaan diri merupakan salah satu faktor penting dalam pemecahan masalah. Achdiyat (2016) berpendapat bahwa anggapan buruk terhadap matematika tambah berkembang saat orang di sekeliling peserta didik memberikan label gagal terhadap peserta didik yang mempunyai nilai matematika rendah. Anggapan itu membentuk keyakinan negatif dalam mereka. Saat lingkungan tidak mendukungnya agar memahami kelemahan serta tidak membantunya agar melihat kelebihan serta potensi yang ada dalam peserta didik sehingga mengakibatkan terkikisnya kepercayaan diri peserta didik. Bandura (2018) berpendapat bahwa kepercayaan diri merupakan perasaan percaya kepada kemampuan diri dalam menggerakkan (memobilisasi) dan menyatukan motivasi dari semua sumber daya yang dibutuhkan, dan memunculkannya dalam tindakan yang selaras dengan apa yang harus diselesaikan, sesuai dengan tuntutan tugas. Dengan adanya rasa percaya diri peserta didik lebih termotivasi dan menyukai matematika. Dalam Permendikbud Nomor 66 Tahun 2013 disebutkan dalam kompetensi dasar khusus matematika yakni memiliki rasa ingin tahu, percaya diri, dan ketertarikan pada matematika serta memiliki rasa percaya diri pada daya dan kegunaan matematika yang terbentuk melalui pengalaman belajar. Kepercayaan diri yang baik Trends International Mathematics and Science Study (2018) yaitu ketika peserta didik mempunyai matematika yang bagus, sanggup belajar matematika secara cepat dan tidak mudah menyerah, menunjukkan perasaan percaya akan keahlian matematika yang dimiliki, dan sanggup berpikir realistik.

Model pembelajaran yang digunakan dalam penelitian ini yakni model pembelajaran yang menuntut peserta didik untuk memahami materi pelajaran dengan baik. Model pembelajaran yang dimaksud yakni model pembelajaran Student Facilitator and Explaining metode Peer Teaching. Trianto (2015) menyatakan bahwa model Student Facilitator and Explaining adalah tipe model Cooperative Learning dengan kelompok-kelompok kecil di mana jumlah anggota tiap kelompok terdiri 4-5 orang peserta didik yang dipilih secara heterogen berdasar kan kemampuan akademis, keanekaragaman gender. Menurut Dianawati (2016), metode Peer Teaching merupakan metode dimana peserta didik terlibat aktif serta satu peserta didik bertugas mengajari teman kelompoknya yang mengalami kesusahan saat 
memahami materi. Seusai pendidik memberikan penjelasan materi, pendidik membagi peserta didik menjadi kelompok yang terdiri dari 4-5 peserta didik secara merata, maksudnya ada yang pandai, sedang serta yang berkemampuan rendah.

\section{METODE}

Penelitian ini menggunakan pendekatan kombinasi (mixed research) yaitu pendekatan pendekatan penelitian yang mengombinasikan atau mengasosiasikan bentuk kualitatif dan bentuk kualitatif (Creswell, 2015). Dengan desain sequantial explanatory, yaitu penelitian campuran yang menggabungkan metode kuantitatif dan kualitatif secara berurutan, di mana pada tahap pertama penelitian menggunakan metode kuantitatif dan pada tahap kedua menggunakan metode kualitatif (Sugiyono, 2018). Jenis penelitian kuantitatif menggunakan quasi experimental design yaitu desain yang mempunyai kelompok kontrol tetapi tidak dapat berfungsi sepenuhnya untuk mengontrol variabel-variabel luar yang memepengaruhi pelaksanaan eksperimen (Sugiyono, 2018). Populasi merupakan wilayah generalisasi terbentuk dari objek/subyek yang memiliki karakteristik serta kuantitas tertentu yang telah ditetapkan oleh peneliti guna ditarik kesimpulannya (Sugiyono, 2018). Populasi dalam penelitian ini adalah peserta didik kelas VII SMP Negeri 2 Sukorejo. Sampel dalam penelitian adalah kelas VIIA sebagai kelas eksperimen dan VIID sebagai kelas kontrol melalui proses pemilihan sampel menggunakan Cluster Random Sampling yaitu teknik sampling daerah yang digunakan untuk menentukan sampel bila obyek yang akan diteliti atau sumber data sangat luas (Sugiyono, 2018). Teknik pengumpulan data kuantitatif menggunakan teknik tes dan angket. Tes adalah teknik yang dipakai dalam rangka melakukan pengukuran yang di dalamnya ada berbagai pernyataan, pertanyaan, atau tugas yang perlu dijawab atau dikerjakan oleh peserta didik guna mengukur aspek perilaku peserta didik (Arifin, 2018). Sedangkan angket adalah teknik pengumpulan data yang dilaksanakan dengan memberi pernyataan atau perntanyaan tertulis pada siswa agar dijawab (Sugiyono, 2018). Teknik analisis data kuantitatif dalam penelitian ini menggunakan uji hipotesis dua pihak dan satu pihak.

Penelitian kualitatif menggunakan jenis penelitian deskriptif kualitatif. Proses pemilihan enam subjek menggunakan teknik purposive sampling yaitu teknik pengambilan sampel sumber data dengan pertimbangan tertentu (Sugiyono, 2018). Pemilihan enam subjek tersebut berdasarkan nilai posttest pemahaman konsep matematika dan angket kepercayaan diri yang memiliki kategori sama yaitu tinggi, sedang, dan rendah. Enam subjek berasal dari tiga subjek kelas ekperimen dan tiga subjek dari kelas kontrol. Teknik pengumpulan data kualitatif menggunakan teknik wawancara. Teknik analisis data kualitatif menggunakan model Miles and Huberman (reduksi data, penyajian data, dan penarikan kesimpulan/verifikasi).

\section{HASIL}

Analisis data kuantitatif dianalisis menggunakan software SPSS 23. Analisis data posttest dilakukan setelah berakhirnya pemberikan perlakuan. Analisis data kuantitatif di analisis dengan uji t dua pihak dan satu pihak. Namun sebelum melakukan uji t dua pihak dan satu pihak hal yang menjadi prasyarat yakni uji normalitas. Uji normalitas dilakukan guna mengetahui apakah data berasal dari populasi yang berdistribusi normal atau tidak. Berikut hasil analisis uji normalitas data posttest pemahaman konsep matematika dilihat pada Tabel 1 .

Tabel 1 Hasil Output Uji Normalitas Data Posttest Pemahaman Konsep Matematika

\begin{tabular}{ccccc}
\hline Kelas & & & Sig & Keterangan \\
\hline Eksperimen & Posttest & PKM & 0,087 & $\mathrm{H}_{0}$ Diterima \\
\hline Kontrol & Posttest & PKM & 0,815 & $\mathrm{H}_{0}$ Diterima \\
\hline
\end{tabular}


Berdasarkan Tabel 1 uji normalitas pada kelas eksperimen dan kelas kontrol di peroleh nilai sig semuanya $>5 \%$, sehingga $\mathrm{H}_{0}$ diterima, yang artinya data Posttest pemahaman konsep matematika berdistribusi normal.

Setelah dilakukan uji normalitas tahap selanjutnya yakni uji t dua pihak. Uji t dua pihak dilakukan untuk mengetahui apakah terdapat perbedaan pemahaman konsep matematika peserta didik pada kelas eksperimen dan kelas kontrol. Berikut hasil analisis data kuantitatif menggunakan pemahaman konsep matematika dapat dilihat pada Tabel 2.

Tabel 2 Hasil Analisis Perbandingan Pemahaman Konsep Matematika

\begin{tabular}{|c|c|c|c|c|}
\hline Equal & & & Sig (2-tailed) & Keterangan \\
\hline Variance & Posttest & PKM & 0,000 & $\mathrm{H}_{0}$ ditolak \\
\hline
\end{tabular}

Berdasarkan perhitungan menggunakan software SPSS 23 Tabel 2 diperoleh nilai sig(2-tailed) $<5 \%$ berarti terdapat perbedaan yang signifikan pemahaman konsep matematika siswa kelas yang diberi perlakuan model SFE metode Peer Teaching dengan kelas yang diberi perlakuan model pembelajaran konvensional

Selanjutnya yakni uji hipotesis satu pihak yang digunakan untuk mengetahui manakah pemahaman konsep matematika yang lebih baik yang menggunakan model Student Facilitator and Explaining metode Peer Teaching dengan kelas yang menggunakan model pembelajaran konvensional. hasil analisis uji-t satu pihak untuk pemahaman konsep matematika diperoleh $t_{\text {hitung }}>t_{\text {tabel }}$ atau 5,2197155908 $>1$,99897. Artinya $\mathrm{H}_{0}$ ditolak sehingga pemahaman konsep matematika akhir kelas yang diberi perlakuan SFE metode Peer Teaching lebih baik daripada kelas yang tidak diberi perlakuan.

Analisis data angket kepercayaan diri sama halnya dengan analisis data posttest yang dilakukan yakni uji normalitas, uji hipotesis dua pihak dan satu pihak. Analisis angket tidak dapat langsung di ujikan di software SPPS 23 karena datanya masih ordinal harus di rubah terlebih dahulu ke data interval menggunakan software MSI. Berikut hasil uji normalitas pada data angket kepercayaan diri peserta didik dilihat di Tabel 3.

Tabel 3 Hasil Output Uji Normalitas Data Angket Kepercayaa Diri

\begin{tabular}{ccccc}
\hline Kelas & & & Sig & Keterangan \\
\hline Eksperimen & Tahap Akhir & Kepercayaan Diri & 0,669 & $\mathrm{H}_{0}$ diterima \\
\hline Kontrol & Tahap Akhir & Kepercayaan Diri & 0,669 & $\mathrm{H}_{0}$ diterima \\
\hline
\end{tabular}

Berdasarkan Tabel 3 uji normalitas diperoleh nilai sig > 0,05, maka $\mathrm{H}_{0}$ diterima. Artinya kedua kelas berasal dari populasi yang berdistribusi normal.

Selanjutnya uji hipotesis dua pihak yang dilakukan guna mengetahui apakah terdapat perbedaan kepercayaan diri antara kedua kelas tersebut. Berikut hasil outuput uji hipotesis dua pihak angket kepercayaan diri apat dilihat pada Tabel 4.

Tabel 4 Hasil Analisis Perbandingan Angket Kepercayaan Diri Tahap Akhir

\begin{tabular}{|c|c|c|c|}
\hline Equal & & Sig (2-tailed) & Keterangan \\
\hline Variance & Tahap Akhir & 0,005 & $\mathrm{H}_{0}$ ditolak \\
\hline
\end{tabular}

Selanjutnya uji hipotesis satu pihak yang digunakan untuk mengetahui manakah yang lebih baik kepercayaan diri peserta didik antara kelas eksperimen dan kelas kontrol. Hasil analisis uji hipotesis satu pihak angket kepercayaan diri diperoleh $t_{\text {hitung }}>t_{\text {tabel }}$ atau $2,8668590521>1,99897$. Artinya $\mathrm{H}_{0}$ ditolak sehingga kepercayaan diri siswa kelas yang diberi perlakuan model pembelejaran Student Facilitator and Explaining metode Peer Teaching lebih baik daripada kelas yang diberi perlakuan model konvensional.

Analisis data kualitatif menggunakan deskriptif kualitatif. Teknik pengumpulan data menggunakan wawancara dan observasi. Sementara pengujian credibility data dilakukan 
dengan teknik triangulasi. Teknik triangulasi adalah teknik untuk menguji kredibilitas data dilakukan dengan cara mengecek data kepada sumber yang sama dengan teknik yang berbeda (Sugiyono, 2018).

Observasi dilakukan saat proses pembelajaran berlangsung tiap pertemuan. Selama proses pembelajaran peneliti dibantu oleh dua observer yaitu ibu Milasari Renaningtyas, M.Pd selaku guru matematika kelas VII SMP Negeri 2 Sukorejo sebagai observer I dan Ainiyatul Aliyah selaku teman sejawat sebagai observer II. Rata-rata lembar observasi kegiatan pendidik dan peserta didik dapat disimpulkan bahwa pelaksanaan pembelajaran dengan model SFE dengan metode Peer Teaching dan model pembelajaran konvensional sudah berjalan dengan baik.

Pada kelas eksperimen subjek dengan kategori tinggi dapat memenuhi semua indikator pemahaman konsep matematika dan kepercayaan diri. Sementara subjek kategori sedang telah memenuhi empat dari lima indikator pemahaman konsep matematika karna pada indikator pengaplikasian pada kehidupan sehari-hari subjek deng kategori sedang masih belum mampu dan masih bingung dalam menyelesaikannya, untuk kepercayaan diri subjek telah mampu memenuhi tiga dari empat indikator kepercayaan diri. Sedangkan subjek dengan kategori rendah hanya mampu memenuhi tiga dari lima indikator pemahaman konsep matematika dan untuk kepercayaan diri hanya mampu memenuhi dua dari empat indikator kepercayaan diri peserta didik.

Pada kelas kontrol subjek dengan kategori tinggi telah memenuhi empat dari lima indikator pemahaman konsep matematika dan tiga dari empat indikator kepercayaan diri. Sementara subjek dengan kategori sedang telah mampu memenuhi tiga dari lima indikator pemahaman konsep matematika dan dua dari empat indikator kepercayaan diri peserta didik. Sedangkan subjek dengan kategori rendah hanya mampu memenuhi satu dari lima indikator pemahaman konsep matematika dan hanya memenuhi satu dari empat indikator kepercayaan diri peserta didik.

Hasil analisis data kualitatif kelas eksperimen rata-rata telah memenuhi semua indikator pemahaman konsep matematika dan kepercayaan diri, sementara pada kelas kontrol peserta didik hanya memenuhi sebagian indikator pemahaman konsep matematika dan kepercayaan diri.

\section{PEMBAHASAN}

Hasil penelitian kuantitatif terdapat perbedaan pemahaman konsep matematika dan kepercaan diri siswa kelas yang diberi perlakuan model SFE dan metode Peer Teaching dengan kelas yang diberi perlakuan model pembelajaran konvensional. Dan diketahui bahwa pemahaman konsep matematika dan kepercayaan diri kelas eksperimen lebih baik daripada kelas kontrol. Beberapa hal yang menyebabkan kelas ekperimen lebih baik pemahaman konsep matematika dan kepercayaan dirinya daripada kelas kontrol. Salah satu penyebabnya adalah model SFE metode Peer Teaching didesain untuk belajar secara berkelompok dan menuntut peserta didik untuk berusaha mempelajari sendiri materi karena hasil belajar di diskusikan kepada teman sekelasnya sehingga siswa harus memahami materi, dan siswa yang kurang memahami akan terbantu dengan materi yang diajarkan oleh temannya sendiri. Pembelajaran model Student Facilitator and Explaining metode Peer Teaching dapat meningkatkan pemahaman konsep matematika dan kepercayaan diri peserta didik karena dalam proses pembelajaran, peserta didik dilibatkan dalam kelompok dan mempresentasikan di depan teman sekelasnya sehingga mampu membangkitkan kepercayaan diri pada kemampuannya dan memengaruhi pola interaksinya. Peserta didik tidak terlalu bergantung pada guru, namun dapat menambah penguasaan materi yang diperoleh dari berbagai sumber dan belajar dari teman-temannya yang memiliki kemampuan akademisnya lebih tinggi. Hal tersebut diperkuat oleh Shoimin (2014) yang menyatakan bahwa model pembelajaran Student 
Facilitator and Explaining adalah model Cooperative Learning dirancang guna memengaruhi pola interaksi peserta didik bertujuan meningkatkan penguasaan materi. Sementara menurut Trianto (2015) model Student Facilitator and Explaining merupakan model Cooperative Learning yang dibagi menjadi 4-5 peserta didik yang dibagi secara heterogen berdasarkan kemampuan akademis, keanekaragaman gender. Sementara Haris (2018) menyatakan bahwa metode pembelajaran Peer Teaching adalah di mana peserta didik saling memberikan pengetahuannya kepada sesama rekannya atau mengajar teman sejawatnya, sehingga dalam proses pembelajaran ini peserta didik dapat melatih cara berkomunikasi dan menyampaikan pendapat.

Proses pembelajaran kelas kontrol menggunakan model pembelajaran konvensional, lebih memfokuskan pada kegiatan guru dibandingkan pada kegiatan peserta didik. Selain itu, guru juga tidak memberikan kesempatan peserta didik untuk terlibat aktif dalam proses pembelajaran seperti, tidak diberikan kesempatan untuk berdiskusi dengan temannya, tidak memberikan kesempatan kepada peserta didi untuk bertanya, dan guru hanya fokus menjelaskaan materi. Dengan proses model pembelajaran konvensional menyebabkan peserta didik kurang memahami materi dan konsep matematika dengan mudah. Sehingga model Student Facilitator and Explaining metode Peer Teaching lebih baik daripada model konvensional dan dapat meningkatkan pemahaman konsep matematika dan kepercayaan diri peserta didik.

Penelitian kualitatif dilakukan pada tahap kedua, hasil penelitian kualitatif mendukung hasil penelitian kuantitatif pemahaman konsep matematika dan kepercayaan diri. Sesuai perolehan analisis data penelitian kualitatif pemahaman konsep matematika dan kepercayaan diri peserta didik melalui hasil wawancara, dibedakan menjadi tiga kategori, yaitu kategori tinggi, sedang, dan rendah. Berlandaskan hasil wawancara dan nilai tes pemahaman konsep matematika serta kepercayaan diri peserta didik perolehannya tidak berbeda jauh daripada kelas yang diberi perlakuan model Student Facilitator and Explaining metode Peer Teaching. Namun untuk tingkat pencapaian indikator masih unggul yang di kelas yang diberi perlakuan model SFE metode Peer Teaching.

\section{SIMPULAN DAN SARAN}

Berdasarkan hasil penelitian yang telah dilaksanakan mengenai pemahaman konsep matematika dan kepercayaan diri peserta didik kelas VII SMP Negeri 2 Sukorejo pada materi segiempat dan segitiga yang diberi perlakuan model SFE metode Peer Teaching, maka diperoleh simpulan bahwa terdapat perbedaaan pemahaman konsep matematika dan kepercayaan diri peserta didik kelas eksperimen dengan kelas kontrol, pemahaman konsep matematika dan kepercayaan diri peserta didik kelas eksperimen lebih baik daripada kelas kontrol. Berdasarkan analisis data kualitatif diperoleh pemahaman konsep matematika dan kepercayaan diri peserta didik perolehannya tidak berbeda jauh daripada kelas yang diberi perlakuan model Student Facilitator and Explaining metode Peer Teaching. Namun untuk tingkat pencapaian indikator masih unggul yang di kelas yang diberi perlakuan model Student Facilitator and Explaining metode Peer Teaching dibandingkan model pembelajaran konvensional.

Berdasarkan kesimpulan diatas peneliti mengusulkan beberapa saran sebagai berikut: (1) Guru perlu lebih kreatif dalam memberikan model pembelajaran agar dapat meningkatkan kompetensi yang diberikan di dalam pembelajaran matematika; (2) model SFE dan metode Peer Teaching dapat dijadikan sebagai bahan pertimbangan dalam mengambil kebijakan untuk meningkatkan kualitas pembelajaran; (3) peserta didik perlu lebih banyak berlatih memahami materi dan berlatih mengerjakan soal-soal yang dapat meningkatkan pemahaman konsep matematika dan kepercayaan diri peserta didik; serta (4) bagi peneliti agar lebih kritis dalam mengahadapi atau melihat masalah-masalah dalam pembelajaran. 
DAFTAR RUJUKAN

Achidyat, M. (2016). Prestasi Belajar Matematika Ditinjau dari Kepercayaan Diri dan Keaktifan Siswa Di Kelas. Jurnal Formatif. Vol 6 (1): 50-61.

Afrilianto, M. (2012). Peningkatan Pemahaman Konsep dan Kompetensi Strategis Matematis Siswa SMP dengan Pendekatan Metaphorical Thinking, Jurnal Ilmiah Program Studi Matematika STKIP Siliwangi, Vol 1 (2), 192-202.

Arifin, Z. (2014). Evaluasi Pembelajaran. Bandung: Rosdakarya.

Bandura, A. (1997). Social Learning Theory. Prentice-Hall, Inc., New Jersey.

Creswell, J. W. (2015). Research Design Pendekatan Kualitatif, Kuantitatif, dan Mixes. Yogyakarta: Pustaka Belajar.

Dianawati, H. (2015). Pengaruh Penerapan Metode Peer Teaching dalam Pembelajaran Matematika Terhadap Peningkatan Prestasi belajar siswa kelas VI SDN Giring 1 Kecamatan Manding Kabupaten Sumenep. Jurnal "MITSU" Media Informasi Teknik Sipil UNIJ”. Volume 3 (1): 27-37.

Haris, I. N. (2018). Model Pembelajaran Peer Teaching dalam Pembelajaran Pendidikan Jasmani. Jurnal Ilmiah FKIP Universitas Subang. Vol 4 (1).

Hudojo. (1998). Strategi Belajar Mengajar, (Malang: IKIP 1990).

Permendikbud. (2013). Peraturan Mmenteri Pendidikan dan Kebudayaan Nomor 68 Tahun 2013 tentang Kerangka Dasar dan Struktur Kurikulum Sekolah Menengah Pertama/Madrasah Tsanawiyah.

Purwaningsih, A. (2016) Peningkatan Pemahaman Konsep Pembelajaran Matematika Melalui Pendekatan Reciprocal Teaching Siswa SMP Kelas VII. Skripsi Pendidikan Matematika Fakultas Keguruan dan Ilmu Pendidikan, Surakarta: Universitas Muhammadiyah Surakarta.

Shoimin, A. (2014). 68 Model Pembelajaran Inovatif dalam Kurikulum 2013. Yogykarta: Arruz Media.

Sholeha, R. (2016). Penerapan Metode Mind Mapping dan Model Student Facilitator and Explaining untuk meningkatkan hasil belajar peserta didik kelas VIII A pada materi Sisterm Respirasi di SMP Aisyiyah Muhammadiyah 3 Malang, Jurnal Edukasi Matematika dan Sains. Volume 4 (2): 121-128.

Sugiyono. (2018). Metode Penelitian Kuantitatif, Kualitatif, dan R\&D. Bandung: PT Alfabeta Bandung.

Trianto. (2007). Model-model pembelajaran Inovatif Beroreientasi Kontruktivisme. Surabaya: Prestasi Pustaka Publisher. 